\title{
下顎骨と怪骨に発生した多発性 骨原発血管腫の一例
}

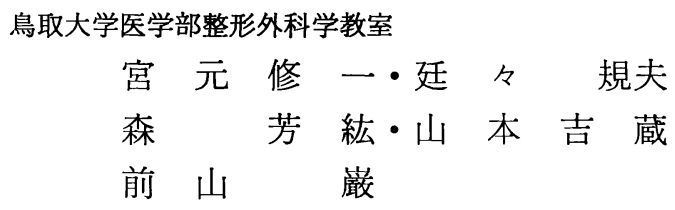

\section{Multiple Primary Hemangiomas of Bone in the Mandible and the Tibia. A Case Report}

\author{
By \\ S. Miyamoto, N. Teitei, Y. Mori, \\ K. Yamamoto and I. Maeyama \\ Department of Orthopaedic Surgery, Tottori \\ University School of Medicine
}

\begin{abstract}
A female aged fourty-eight noticed a bony mass, $2.5 \times 2.0 \mathrm{~cm}$, on the left side of the mandible, which was of a year long duration although it had not caused pain and other symptoms. A radiograph showed a coarse "honey comb" rarefaction and characteristic radiating spicules in the tumor of the mandible.

A tumor in the tibia happened to be found by radiological screening. No bony mass was palpated on the antero-medial aspect of the right tibia, but radiological picture revealed a latticed texture, so-called "corduroy cloth" appearence.

Pathologically, both specimens of the mandible and the tibia showed dilated, endothelial-lined vascular channels with red blood cells.
\end{abstract}

骨の血管性起源の腫場として，良性と考えられるも のに骨血管腫が あるが，その発生頻度は 比較的まれ で， 全国骨腫場患者登録一覧表（昭和 47 年 51 年） によると，原発性骨腫汮 4260 例中，骨血管腫は 36 例である．さらに全身性骨原発血管腫は 6 例であり， 非常にまれである. 今回，われわれは，下顎骨之右脛 骨に発生した多発性骨原発血管腫を経験したので報告 する。

\section{症例}

患者：48才，女性.

\section{主訴：下顎部腫㿔形成}

現病歴：約 1 年前, 下顎部腫瘤形成に気付いたが, 疼痛むなく放置していた．約 2 力月前, 某病院整形外 科を受診したとてろ，エックス線像にて下顎骨のほか に, 右脛骨にあ格子状異常陰影を指摘され, 当科に紹
介された。

既往歴：特記すべきことなし

家族歴：特記すべきことなし

生活歴：特記すべきととなし

現店: 下䫟骨のオトガイ隆起右側部に母指頭大, 半 球状の腫瘤形成と，同部に軽度の圧痛が認められた。 右下腿には外見上とくに異常は認められなかった.

エックス線像: 下顎骨正面像にて, 腫㾇形成部に一 致して，境界不鮮明な円形の蜂窩状透明巣が認められ 側面像および軸射像にて腫瘤中心部より放射状に走る sun-burst 状陰影が認められた（図 1)。 また，右脛 骨正面像にてその骨幹部中央部に格子状透亮陰影か認 められた (図 2).

骨シンチクラム：下顎骨および右脛骨に ${ }^{99 \mathrm{~m}} \mathrm{Tc}$-ピ ロリン酸の異常集皘像は認められなかった.

血管造影：右下腿に新生血管の增生・蛇行・迁回・ 


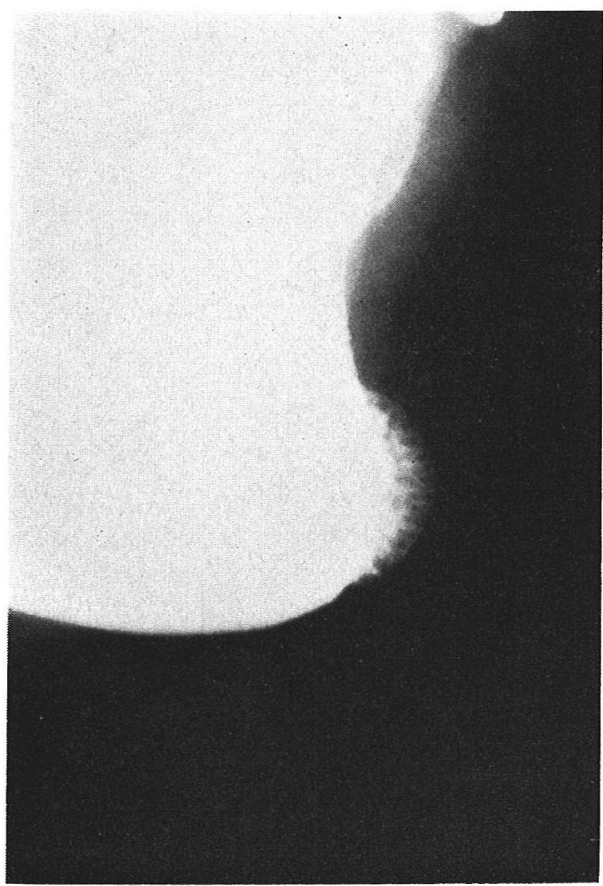

図 1 下顎骨側面像

腫籀中心部より放射状に走る sun-burst 状㓌影が認められる。

綱状形成あるいは走行変化などの所見を認めることは 出来なかった。

検查所見：血液一般検查には異常は認められなかっ た.また血清生化学検查では，蛋白分画で，アルブミ ン值の低下と テーグロブリン值の増加を認めたが， 総 蛋白・Al-P-ase・ $\mathrm{LDH} ・ \mathrm{GPT} ・ \mathrm{GOT} ・ \mathrm{Ca} ・ \mathrm{P}$ など は正常值を示した。

治療：多発性骨原発血管腫の診断の屯とに下顎骨お よび右脛骨の病巣部切除術を施行し，下顎骨には骨セ メント充填，右脛骨には自家腸骨片移植を行なった．

手術所見：下顎骨病巣部は半球状に膨隆して扣り, 表面は赤紫色を呈していた. $2 \times 2.5 \times 1 \mathrm{~cm}$ の大き さの腫瘤を切除するに，腫瘤基底部は蜂䈑状を呈し， 出血はほとんど認められなかった，右脛骨病巣部は表 面が赤紫色を呈していたが，骨膨隆は認められなかっ た. $3.5 \times 1.5 \times 2.0 \mathrm{~cm}$ の大きさの脛骨病巣部を切除 するに，病巣内部の骨梁配列は不規則であった。 ま た，下顗骨病巣部・右脛骨病巣部ともに表面を扣扰う 骨膜にまで腫瘍の侵蝕は認められなかった。切除した 下擷骨病巣部を水平切断すると，骨梁が腫瘍基底部よ

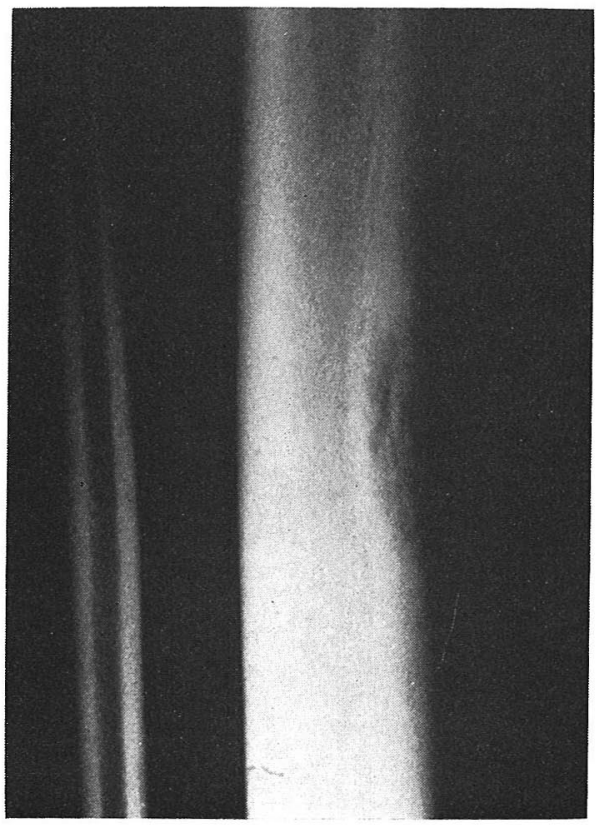

図 2 右脛骨正面像 脛骨中央肉側部飞格子状陰影が認められる。

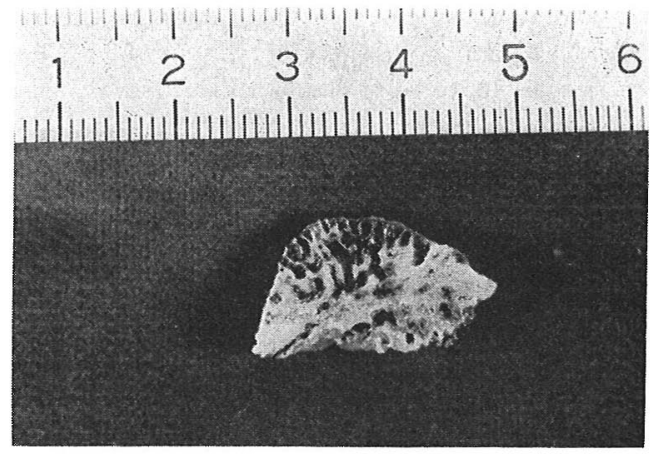

図 3 下顎骨病巣部水平切断割面

粗な骨梁が腫瘍基底部より放射状飞拡がって いる.

り放射状に拡がつており，ソフテックス像にて，sunburst 状陰影として認められた（図 3 ).

また，切除した右脛骨病巣部を縦切断すると，骨梁 の配列が不規則であり，ソフテックス像にて，格子状 陰影として認められた（図 4).

組織学的所見: 下顎骨病巣部, 水平切断標本を $\mathrm{H}$ ・ E染色弱拡大にてみると，太い骨梁と拡張せる血管腔 との集合よりなり，血管腔内は多数の赤血球により充 満されていたが，器質化した血栓は認められなかっ 


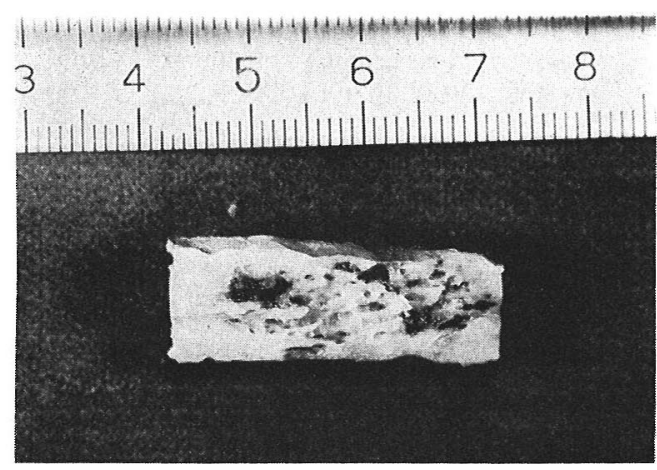

図 4 右脛骨病巣部縦切断割面

た。また，骨膜には腫瘍組織の侵襲はなく，血管腔内 膜を被っている内皮組胞の異型性などもなく，昰性像 は認められなかった，強拡大にてみると，うすい血 管壁を有する多数の血管腔よりなる hemangioma cavernosum の像を呈していた（図5).

次に，右脛骨病紧部，横切断標本をみると，多数の 血管を形成する腫瘍組織が認められ，下顎骨病巣部と 同様の所見を呈していたが，骨質は腫瘍組織により破 壊吸収されていた。

$$
\text { 考察 }
$$

原発性骨血管腫の発生頻度は，全国骨腫瘍患者登録 一覧表（昭和 47 年～51 年）に上ると，原発性骨腫瘍 4,260 例中 36 例 $(0.8 \%)$ であり少なく，その大部分 は単発性であり，多発性に発生したものは 36 例 中 6 例だけで，きわめてまれである，欧米の文献では，骨 外病変をともなわぬ多発性骨原発血管腫は Gutierrez ら (1972) が自験例 1 例と文献上 10 例を報告し，そ の後 Karlin ら (1977) が 1例を報告しているにすぎ ない。

一方 Töpfer らの報告によると，2,000 椎体以上の 剖検例中，267 椎体（約 $12 \%$ ）飞骨血管腫を認めて おり，無症状で，臨床的になんらの異常を訴えないま ま経過する症例が多数あるものと推察される。

原発性骨血管腫の男女別発生頻度は，全国骨腫瘍患 者登録一覧表（昭和 47 年～51 年）によると，男 15 例，女 21 例であり大差はない。 また，諸家の報告に おいても男女別発生頻度に大差はない。

年令別発生頻度は, 各年令層に著明な変動は認めら れなく，幼小児から高令者まで一様に分布している。

病因としては現在のところ, vascular tumor the-

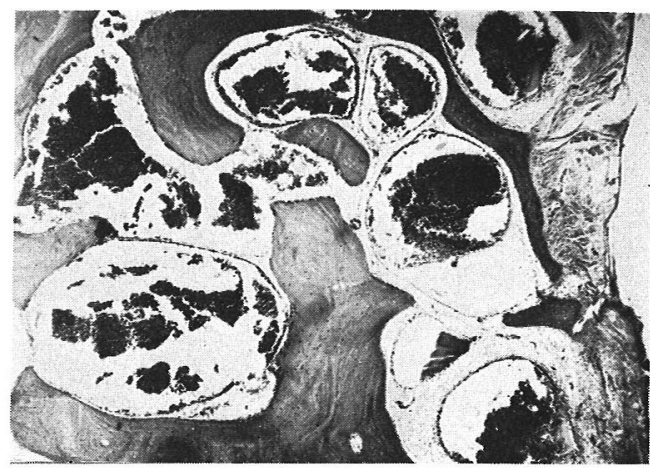

図 5 組 織 像 $(\mathrm{H} \cdot \mathrm{E}$ 染色 $\times 40)$

骨梁間に拡張した血管腔を多数みとめる。

ory と malformation theory の 2 つがあるが定説 はない。

治療法は, 外科的病巣部切除術, 放射線療法, 化学 療法などが行なわれているが，文献上放射線療法と化 学療法はさほど効果が認められていない。

骨外病変をともなわぬ多発性骨原発血管腫の予後は よく, Gutierrez らの報告によると11例中死亡例 は 1 例のみで，その 1 例も死因は本腫瘍とは関連のない ものであった。

\section{結}

語

以上，最近経験した骨外病変をともなわぬ多発性骨 原発血管腫を報告し，若干の文献的考察を加えた.

（本研究は厚生省がん研究助成金の補助による.）

文献

1) Karlin, C. A., and Brower, A. C.: Multiple primary hemangiomas of bone. Am J. Roentgenol. 129: 162-164, July 1977.

2) Gutierrez, R. M., and Spjut, H. J.: Skeletal angiomatosis: report of three cases and review of the literature. Clin. Orthop. 85: 82-96, 1972

3) Wallis, L. A., Asch, T., and Maisel, B. W.: Diffuse skeletal hemangiomatosis: A report of two cases and review of literature. Am. J. Med. 37. 545-563, 1964.

4) Sherman, R. S., and Wilner, D: The roentgen diagnosis of hemangioma of bone. Am. J. Roentgenol. 86: 1146-1159, 1961.

5) Brower, A. C., Culver. J. E., and Keats, T. E.: Diffuse cystic angiomatosis of bone : report of two cases. Am. J. Roentgenol. 
118: 456-463, 1973.

6) Boyle, W. J. : Cystic angiomatosis of bone. J. B. J. S. B-54: 626-636, 1972.

7) Unni, K., and Ivins, J. C., Beabout, J. W., and Dahlin, D. C.: Hemangioma, he- mangiopericytoma and hemangioendothelioma (angiosarcoma) of bone. Cancer. 27: 1403-1414, 1971 .

8）松野誠夫・他：骨の primary haemangioma について. 北北海道整災誌. 6:186-192， 1960. 